\title{
EXAMINING THE IMPACT OF PARENTAL SOCIALIZATION ON THE COPING STYLES OF BLACK GRADUATE STUDENTS FACED WITH MICROAGGRESSIONS
}

\author{
Robert D. Colbert, Kai M. Perry and Marcia Anderson \\ University of Connecticut
}

In recent years, colleges and universities have experienced an increase in the number of Black students who enroll (U.S. Department of Education 2015). Navigating the college adjustment process for many Black students is met with a unique variety of challenges. Social scientists have examined various stressors experienced by Black students in an attempt to explain unfavorable college outcomes such as low grade point average and decreased academic motivation. Factors such as poor academic preparedness and financial difficulties are the most commonly sited predictors of poor college adjustment (Allen 1992; Fleming 1984). However, many studies suggest that stressors within the college environment itself also contribute to the college adjustment of Black students (Allen 1992; Banks 2010; Smedley, Myers, and Harrell 1993). On predominantly White college and university (PWCU) campuses, Black students may experience minority status stress, a psychosocial form of stress related to one's racial and ethnic background. Examples of such stressors may include exposure to racial discrimination (and/or microaggressions), racial and ethnic underrepresentation, being a first generation college student, and strained relationships with professors of a different race and ethnic group (Greer 2008; Greer and Chwalisz 2007).

This article provides an intimate perspective on the experiences of two Black female doctoral students enrolled in a math course at a public, White university (PWU) in the northeast region of the U.S. Both students share personal accounts of the microaggressions they experienced from a math professor of a different racial and ethnic background. Divergent coping strategies are explored as well as how each of their unique racial socialization processes facilitated different behaviors in response to the professor's discriminatory behavior. The experiences shared here have implications for staff of college counseling centers, college admission offices, etc. Recommendations for diversity awareness programs that attempt to improve the racial climate on college campuses are also discussed. 


\section{MicROAGGRESSIONS}

Colleges and universities have an array of departments, programs, directors, centers and even strategic plans all aimed at insuring students from traditionally underrepresented groups receive quality education unencumbered by any forms of discrimination. Despite such efforts to promote equity and inclusion, Black students attending PWCUs still endure racial discrimination on these campuses. The stories of the two Black doctoral students will add another layer to this growing phenomenon. The type of discrimination experienced by the second and third author of this manuscript is termed microaggressions. According to Sue and Sue (2013), microaggressions are "brief and commonplace, daily, verbal or behavioral indignities, whether intentional or unintentional, that communicate hostile, derogatory, or negative racial slights and insults that potentially have a harmful or unpleasant psychological impact on the target person or group" (153).

The university in this story is one with ongoing endeavors to eliminate microaggressions. For example, all faculty and staff in the university must undergo periodic diversity training, which is delivered by staff members from the Office of Diversity and Equity and all university Cultural Centers. Additionally, the school in which these doctoral students engage in their program of studies, has its diversity Action Plan in which activities are undertaken to make sure the environment of the school, i.e. student to student interaction, professor to students interactions are free from microaggressions and any such forms of discrimination.

\section{Case Examples}

Student M: As I began to finish up a particular math class for the fall semester, I had made up my mind that I wanted to keep the same professor for part two the following semester. At this point in the class, I was feeling content that I had made a connection with my professor. Further, I felt good about the time and energy I had put into the class, which was rewarding since the lowest grade of all my assignments was 85. Staying with the same professor for the following semester's class was a decision that felt right, knowing that I had adapted to this professor's teaching style as well as being very familiar with homework assignments and other course expectations. Further, I had formed connections with classmates and had joined a study group, which was very helpf ul to me when preparing homework assignments. These same classmates had also decided to take part two of this class with the same professor for the following semester. So, my natural instinct was to stay connected to the group so we could study together for part two of the class.

Upon the opening for registration, I immediately registered for the class, knowing that the class was going to fill up quickly. After I com- 
pleted registration, it felt good knowing that I got in and was looking forward to continuing part two of this class the following semester.

I can recall the moment that changed everything, when feelings of anger, frustration and discrimination came to my mind. I was staying up late after typing up an assignment for this class, and after a few hours into the assignment, I received an email from the professor. The email implied that I was having difficulties in the class and the professor recommended that I take another class instead for the following semester. My immediate reaction was disappointment in the professor's approach to tell me that she did not want me in his class for the following semester. As I stopped working on her assignment, and with a deep-sinking feeling in my stomach, I sat and read this same email over and over, about four or five times, trying to read "between the lines" of what the professor was really trying to say to me. Some immediate questions came to my mind: "Is it because I am black that this professor immediately jumped to a conclusion that I would not make it in part two of her class next semester?" "Why couldn't she email me to request a meeting to discuss her recommendation face to face, so she could at least hear my feedback?" "Did others in the class get this same email?" "Why did she pre-judge that I would not make it in her following semester class, knowing that my lowest grade was 85 in her current class?" "Is it because I am Black that she has categorized me to be a person of color who struggles in math?" "Is she correct and should I believe that I am not capable of making it in her class next semester?" "Maybe I should follow her advice and take another class next semester instead of hers."

Student $K$ : With confidence and pride, I eagerly enrolled in the first semester of my doctoral program at a reputable, public university in the northeast region of the U.S. I felt elated to be finally entering into the ultimate phase of my educational pursuits. The confidence I felt derived from reflecting on my ability to face and overcome systemic challenges throughout my educational journey. In a way, being admitted for doctoral study confirmed my belief that I was indeed smart enough to become a scholar and expert in my field. The pride I felt was the same remarkable feeling I had experienced each time I accomplished an academic goal in spite of naysayers. I felt like I had finally arrived! I assured myself that with a few more years of hard work my dream of earning my doctorate would inevitably come true.

A few weeks into the semester, those confident feelings I had inside began to slowly dissipate as I attended my math class each week. I believed that because I had finally earned A's in my Master's level math courses, after a lifetime of feeling incompetent about my math skills that I was prepared to excel in my current math course. I thought I had dispelled the irrational belief that I was not smart enough to understand 
doctoral level math. However, a pesky inkling of self-doubt was trying to resurface.

Refusing to allow self-doubt to reenter my consciousness, I spent long hours studying alone, and with peers, to make sure I met the learning objectives and earned a decent grade. I did not attempt to address the reasons my professor doubted me. After all, throughout the first half of the semester, I had no evidence that she held me to a lower standard than other students in the class. It was just a gut feeling that because I was Black that she expected me to struggle with the content of her course. I was not sure if this feeling was warranted or not so I decided to ignore it and focused on learning the material. However, as the course progressed, my professor revealed hints of racial bias. It wasn't until I spoke with the one other Black student in my class, and yet another Black colleague who was trying to obtain our professor's permission to register for the next math course in our sequence the following semester, that I was able to "connect the dots." Our math professor unfairly grouped the three of us Black students together based on our individual requests and made the bold assumption that we were "struggling" in her class. Further, she tried to convince us that we would not need to enroll in the next level of math because we wouldn't need it for our program.

\section{Microaggression Messages and Themes}

Examining the reported experiences of the microaggressions for both students will reveal the common message and impact. What is very important to understand about microaggressions is the internal impact and potential for psychological and/or emotional harm to the receiver. Recall, microaggressions are "brief and commonplace daily verbal or behavioral indignities, whether intentional or unintentional, that communicate hostile, derogatory, or negative racial slights and insults that potentially have a harmful or unpleasant psychological impact on the target person or group" (Sue et al. 2007, 273). There are three types of microaggressions: micro-assaults, micro-insults, and micro-invalidations. For purposes of this paper, micro-insults will be the focus. Accordingly, "micro-insults are unintended behaviors or verbal comments that convey rudeness or insensitivity or demeans a person's racial heritage identity, gender identity or sexual orientation, outside prep's level of awareness -consciousness, characterized by insulting hidden messages" (Sue et al. 2007, 275). For example, the Chair for a university faculty position search committee states to the comimittee that includes one Black woman and seven White men, I believe the most qualified person should get the job. The underlying message suggests that people of color are given extra, unfair benefits because of their race. The theme associated with this 
example is that of the myth of meritocracy, i.e. statements implying race or gender does not play a role in life successes.

\section{MiCROAGGRESSION IMPACT}

The first author spoke with the professor of the math courses to inquire about making room in her class for student $\mathrm{K}$, which was followed with her (math professor) submitting the email to student M. Once the email was forwarded to student $\mathbf{M}$, she responded as mentioned above, followed by student $\mathrm{K}$ responding as noted as well. The first point in these two cases is that the professor didn't intend to commit a microaggression, she didn't set out to purposely insult the two students. The two students in this case began (when professor communicated her belief they couldn't succeed in her advanced class) at two different "mindsets," yet upon thinking about or processing the professor's communication, ended up in the similar state of mind. This state of mind, which is common to receivers of microaggressions, is one of self-doubt characterized by internal negative self-talk regarding the situation. In this case, the negative self-talk concerned beliefs about one's ability to succeed in a more advanced math course. For example, student M, who began with much self-confidence, soon after receiving the professor's email reflected, "Is she correct and should I believe that I am not capable of making it in her class next semester?" "Maybe I should follow her advice and take another class next semester instead of hers." Next, a comparison of the two students experience of the professor's class prior to and after the microaggression will be presented.

Recall, student $\mathrm{M}$ expressed much confidence up to the point of the professor's suggestion that she not enroll in the next class of the sequence. In fact, student $M$ identified specific experiences within the context of the first course with the professor as evidence to support her selfconfidence. Student K first experienced self doubt prior to hearing about the email from the professor and her recommendation that she not take the next course, as she wrote, "A few weeks into the semester, those confident feelings I had inside began to slowly dissipate as I attended my math class each week." How can these two cases be placed into this discussion about the professor having committed a microaggression toward the Black students when they were in different places in terms of their levels of expressed confidence to succeed in the first math course? The impact of the microaggression for both students was similar in that their sense of academic self-confidence began to deteriorate. Victims of microaggressions become at risk for emotional and psychological harm (depression, anxiety and such) that occurs from internalizing the feelings from the experience, as did the students in this situation (Franklin 1999). 
The common message for the students in this microaggression situation was "Blacks are not smart enough for advanced graduate course work." Additionally, the theme associated with this microaggression was that of the myth of Black intellectual inferiority. At the time of writing this manuscript both students had successfully completed the second math course with the same professor and were feeling quite confident about their academic abilities. How were both students able to advance from a place of risk to their well being as aforementioned? Triple Quandary theory (Boykin and Toms 1985) will be used as a conceptual frame for understanding how the two doctoral students were able to successfully meet the challenge of the microaggression discussed above.

\section{Triple Quandary Theory}

Triple Quandary theory helps explain the nature and content of the racial socialization process for Black children. Racial socialization is considered one of the most pressing responsibilities for Black parents (McAdoo 2002) because it equips youth with the capacity to be psychologically and physically healthy in the context of an oppressive society (Marshall 1995). Triple Quandary, as defined by Boykin and Toms (1985), is a three-part frame guiding Black parents in important aspects of the socialization process for their children. The three areas in which parents must teach their Black children are (1) the American dream, (2) their African heritage, and (3) what it means to live as a member of a marginalized group in the United States. According to Triple Quandary, Black parents know the importance of teaching their children about race and all its implications toward obtaining a quality education in order to "better" oneself. Black parents give their children a foundation for their racial identity's development when they teach Triple Quandary's three principles. These teachings will be highlighted through a further look into the two doctoral students' experience the following semester when entering and participating in the professor's advanced class.

\section{Student K's Triple Quandary Teachings}

Student K comes from an upper middle class background in which both parents were highly educated and pillars of the community. Consistent with tenants of Triple Quandary her parents provided direct teachings for each of the three components of Triple Quandary. Central to their teachings was the notion that education was the key to equalizing the playing field for Blacks and Whites. To ensure their children obtained the type of K-12 education necessary for their children to have even a better life than they did, student $\mathrm{K}$ and her siblings mostly attended private schools during their K-12 schooling. African heritage was central to her learning process given that both parents were academics in 
the subject matter. Thus, Student K received a scholarly approach to her African and Afro-American ancestry, one in which she and her family was its embodiment. Student K experienced a good deal of stress associated with the goals and teachings of her parents and the "racialized" reality experienced from other Blacks and Whites. While Student K's parents' Triple Quandary teachings gave her insight and ability to see racism and oppression their teachings were intertwined with the stress to succeed for herself, her parents, and her race.

\section{Student M's Triple Quandary Teachings}

Student $\mathbf{M}$ grew up in London with parents who had migrated from the West Indies. Although separated by an ocean from the United States, Student M's parents also instilled in her and her siblings all components of Triple Quandary. Relief from the racism experienced in London came from a focus on someday moving to America and obtaining the American dream. During Student M's middle school years, she and her family moved to the U.S. Upon arriving $M$ soon learned that the American dream would not be easily attained and she would have to move through barriers of racism and oppression even worse than those in London. Similar to Student K, Student M's parents held education as the key to overcoming challenges to racism and a means to a better life than her parents who both dropped out of high school. Teachings of her African ancestry ran deep, with family ties back to slavery in the U.S. and other parts of the "Americas". The teachings Student M received were a source of strength and motivation for her to move forward toward her goal of becoming highly educated so that she could help "uplift" herself and her People.

\section{COPING}

With help from their faculty advisor, both doctoral students proceeded to engage in the second math course with similar feelings and reminders from earlier life experiences. Recall, Student K identified a threat to her academic confidence, the resurfacing of that "pesky inkling of self-doubt," early on in the first course by stating, "reflecting on my fifth grade math experience helped me to recognize that my doctoral level math professor did not seem to hold high expectations for me to excel in math." In the university math course and in her private school's fifth grade math class, Student $\mathrm{K}$ was experiencing racial discrimination. Looking at Student K's expressions of oppression in conjunction with her parents' teachings reveals how she developed coping strategies that protected her even today in her doctoral level math class. Student K recalled, "At Montessori, I was one of three Black students in the entire K-8 school. Although some students and teachers were kind to me, I 
remember feeling like they thought I didn't deserve to be there; like they were waiting for me to fail. My parents confidently reminded me that they themselves were more educated than my teachers and that I was getting a better education due to the small classes and individualized attention." Her parents' words here reflect an important message and coping strategy to strive toward greater education even in the face of racism. Student K's parents taught her to anticipate racism as she strived for success. They told her that people, even some Black people, would maintain low expectations for her academic success. However, as she recalls, "every greeting card or note from my father includes his favorite saying, "keep your eye on the prize." The prize, in his estimation, I believe was education, the only way to level the playing field between Blacks and Whites." The coping strategy that Student K took away was that even when you're experiencing racism, despite how bad it makes you feel, you must be reminded of your privilege (the opportunity of higher education), and because that privilege is not afforded to most Blacks, it is your duty to succeed against all odds.

Student $\mathrm{M}$ gained and used the teachings of her parents to effectively cope with the microaggression and succeed in the class the following semester. Upon experiencing racism in the United States for the first time Student M said she felt intense feelings of frustration and anger and immediately took those feelings home and confronted her parents as found in the following words: "Just when I thought I had fled racism when I moved out of London to America, I was foolishly mistaken, as I encountered the same racial oppression not only in my school, but also in my community. It was then that I had questioned my parents on their choice to move since things were not racially better in America. It was at this point in my life where my parents enforced the importance of a quality education, in order to conquer some of the racial inequalities and injustices that are prevalent in society." While both students' (M and K) parents taught that education was the way to counter the racism of life in America, for student $\mathrm{M}$, this core principle of life was taught within the context of her experiencing excruciating feelings associated with being "welcomed" to United States minority status. "Through my years of being educated in high school, undergraduate/graduate College and now my Doctorate, I find myself leaning on the lessons my parents taught me in order to feel empowered, strong and confident as a black female, in a racially unjust society. Student M's coping strategy when there is threat to her achieving the American dream is to stop and confront whomever she believes is responsible. In fact, Student $M$ speaks with much confidence in her ability to confront people in situations deemed racist or oppressive. 


\section{Strategies in Second Course}

Student M: Just prior to the start of the second class, Student M contacted the professor asking for a meeting to talk about the email she sent her stating she thought she should take a different class the following semester. "The day came for us to meet and I felt full confidence to express my thoughts and reaction to her email. I also knew that I had to keep in mind that I needed to be careful in my choice of words when expressing my thoughts, since I did not want to out-right accuse her of something or pre-judge her, just like she had pre-judged me." This meeting ended with the professor apologizing to Student $\mathbf{M}$ for including her in her generalization of the Black students wanting to take her second class.

Once the second class began, Student $M$ did not retreat from her vigilance pertaining to being treated unfairly by the professor, as she notes; "As the new semester began in part two of this class, I already had my guard up with defense mechanisms in place. The feeling of anxiousness was upon me, knowing that I now had to prove that I was worthy and capable of being in her class. As the class progressed, I noticed that I was now putting in more time, energy and hours to complete assignments and achieve a high grade. By mid-semester my lowest grade was 90. Also, by mid-semester I had approached the Professor on two occasions, in order to discuss concerns I had regarding her point-system, comments or discrepancies I found on my returned assignments. A feeling of disappointment would again arise within me, when I noticed that I had the same answer as another group member, but yet my answer was marked wrong and theirs correct. During my discussions, it was apparent that the professor knew what she was doing and she made it obvious that I was being given a difficult time in order to push me to do better. This type of teaching style did not feel comfortable with me, since my feelings of underlying racism was my perception for her motivation.

As the class progressed, I would put my feelings aside and make an extra effort to be nice to the professor. I was now staying a little later at the end of each class, in order to make small-talk and wish her a good afternoon. Once again, another surprise came when she approached me after one of my assignment was returned, and stated that I was doing well in the course. My thoughts were; "did my comments provoke the professor to think about herself and how she was treating me?" "Will she now change her teaching style towards me now that she knows that I will bring my concerns to her attention once I notice discrepancies?" As the class came to a close for that semester, a final thought came to mind; "was there a lesson learned from student to teacher?"

Student K: After experiencing the microaggressions in math the first semester, I responded by disengaging with the professor. I had lost 
some respect for her on a personal level and was only concerned about earning a good grade in the course. I no longer felt safe talking to her about my challenges with the material. I wanted to avoid asking her for help or extra time to work on assignments out of concern that she would mistake such requests as symptoms of weakness. I felt that the professor's biases toward me were deeply embedded in her consciousness and that there was nothing I could do to change her perceptions of me. I believed that no matter how hard I tried, no matter how well I performed on assignments, I would not impress her, nor did I care to try. If I did well on the assignments, I expected that she would attribute my good work to something other than my intelligence, like cheating or getting help from classmates. In fact, in her first semester course, she quizzed me about how I arrived at a certain answer on an assignment while insinuating that I was cheating by getting help from students who took her class prior semesters. Paradoxically, all students in my class were working in small groups to complete the lengthy, difficult assignments. My focus second semester was to simply do my best work while avoiding personal interactions with her. Avoiding her would protect me from "losing my cool" as I feared that if I spoke with her, her implicit racist attitudes would become too apparent for me to ignore or to address politely. If I had to confront her, I feared that she would use her power to punish me by giving me a lower grade than I deserved. Thus, I focused on the course material, and tried my best to ignore her racist ideals, in effort to avoid confrontation and make a good grade in the course. I did what my father had taught me and "kept my eye on the prize."

\section{Discussion}

Microaggressions offer a framework for enhancing the understanding of Black's experiences of minority status stress (Greer and Brown 2011). Moreover, probing the impacts of microaggressions can reveal the nature of the stress for the individual, i.e. depression, anxiety. Further, by adding Triple Quandary to an exploration of microaggressions, more dimensions of importance emerge (i.e. coping strategies) that might contribute to the growing knowledge base of minority status stress. Two dimensions that have emerged when considering Triple Quandary in this paper are parental teachings function to provide a foundation for Black students to move successfully through the United States schooling system and beyond, and the continuity in processes associated with minority status stress between early (K-12) and later post secondary racial discrimination in the educational setting. 


\section{Parental Teachings}

The way in which a microaggression situation is addressed, i.e. do students' lived experience become validated or invalidated, is important for understanding minority status stress. Parents of the two students in this paper validated their racial discriminatory experiences during their $\mathrm{K}-12$ educational years, thus provided protection against their potential harmful effects and future coping capacities. However, stating that parents gave their children protection does not mean such children no longer require further support in addressing microaggressions. Even with early parental protection in the form of validating of oppressive experiences both students remained vulnerable to the harmful impacts of microaggressions. More on students' vulnerabilities is presented below in addressing the notion of continuity of educational experiences, but first greater details regarding parental teaching resumes. As the students' advisor reflected on the microaggression, he recalled:

When the professor communicated her concerns regarding all three Black students in her class, I did not question the professor. I hadn't been in communication with the students about their experience in the professor's class, thus, I didn't have any basis to counter the professor's claims. However, when I sat face to face with the doctoral students listening to their expressions of sadness, disappointment, frustration, as they related how the professor's actions had "landed" on them - their lived experience, I immediately provided my full support by validating what they had experienced. The moment I validated the students' lived experiences, I "stepped in" for their parents [in loco parentis] in protecting them from further harm from the microaggression.

Further harm could have occurred in the form of a more permanent loss of academic self-esteem, and in the faculty advisor as a trusting supporter. Support from the advisor protected the students from further harm so both could implement coping strategies learned from their parents' teachings (Johnson-Bailey, Valentine, Cervero, and Bowles 2008).

The parental teachings of both students demonstrate that Blacks continue to share a common bond when it comes to racism. First, both experienced the microaggression as yet another challenge to reaching their greater goal of higher education or the American dream (Boykin and Toms 1985). Additionally, both students' parents taught them that to achieve their American dream they would need to be able to effectively navigate through structural barriers of racism. For Blacks, achieving the American dream is more than just advancing in life as an individual and 
perhaps reaching middle class status. It also means if one succeeds in reaching this Dream, one's "people" (Blacks as a collective group) are uplifted. Academic success, therefore, is both an individual and collective goal as a result of the racialized teachings these students received from their parents (Carter 2008).

\section{Coping Strategies}

Silver and Wortman (1980) define coping as "any and all responses made by an individual who encounters a potentially harmful outcome" (281). Carter (2008) asserts that successful Black "students develop adaptive strategies. . . for overcoming racism that allow them to maintain high academic achievement and strong racial/ethnic self-definitions" (489). Coping with racial microaggressions in an academic environment can be demonstrated in varying degrees of resistance to stressors (Carter Andrews 2012). In this case, the source of stress for Students K and M stemmed from the microaggression that inaccurately and unfairly attributed their race as an indicator of their academic abilities. While both graduate students demonstrated different coping strategies, both styles protected them from internalizing a victimization mentality and allowed these students to maintain their positive achievement ideologies in order to reach their American dreams.

Roth and Cohen (1986) describe two coping strategies: approach and avoidant. With approach coping strategies, the individual makes an attempt to confront or resolve the stressor. Whereas with avoidant strategies, the individual distances herself from the stressor or reframes her thinking about the problem. Student K employed an "avoidant coping strategy" by deciding not to confront the professor about the microaggression, which according to Carter (2008) could be a survival strategy that "protects her emotional and mental health in the classroom environment (491)." If Student K had chosen to confront the professor, the professor could have revealed even more racist notions which could have potentially threatened Student K's race/achievement identity. For Student $\mathrm{K}$, that threat was not worth risking her academic success, especially at the Ph.D. level. By "avoiding" confrontation, Student K was able to simultaneously maintain her positive Black identity and academic self-confidence. Alternatively, Student M employed an "approach coping strategy" by confronting the professor in attempt to resolve her concerns about the racial microaggression. Student M's problem solving approach, although quite different than Student K's, similarly enabled her to persist in the class and maintain her Black identity despite the perceived denigration (Carter Andrews 2012). 


\section{RESPONSE CONTINUITY}

Response continuity of racial discriminatory experiences refers to a child's initial and/or early experiences, the adults' response(s) to the experience(s) (validated or not validated) and whether adults/parents are able to attach meaningful (racially based) learning to the experience. As children and adolescents progress through their formal schooling discriminatory situations can occur one after another. Individuals from marginalized groups (including school-age children) can experience multiple microaggressions on a daily basis. Black children can enter the schooling process with their "smart selves" intact, only to be challenged by the kinds of racially based experiences described by the two doctoral students in this paper. In a research study on Black parental involvement in their children's education, a consistent theme reported by parents, was their puzzlement pertaining to the difficulties of their children's academic self-esteem remaining intact upon entering the public school setting (Colbert 1991). As shown in the case examples in this article, racial discrimination experienced in early educational settings can continue throughout higher education. Thus, it is important to their well being and academic self esteem that some trusted "adult" continue to validate the experiences and provide meaning that is consistent with early parental teachings.

\section{IMPLICATIONS}

\section{K-12 Education}

For children and adolescents in grades K-12, we would need to take a closer look at what they are experiencing during this stage of their lives. Specifically, for children of color, those who might externalize their coping skills when dealing with microaggression could be perceived as defiant, unruly and combative. Research showing that students of color are issued disproportionately more disciplinary sanctions when compared to White students supports our contention here that if students of color attempt to communicate their experiences of racism within the school setting, their behavior might be misread as discipline issues (Gregory, Skiba, and Noguera 2010). Even though their intentions may be to communicate a basic learning need (feel positive about themselves and other members of their reference group) their behavior could be misinterpreted as disruptive and out of control. It is perhaps unreasonable to expect children and even adolescents to have skills needed to effectively communicate their perceptions of microagressions to adults who might have been the deliverers of those negative behaviors. Colbert (in press) recommends that school counselors advocate for students by conducting analyses of interactions among teachers and students using Helms' Ra- 
cial Identity Interaction Model (Helms 2003). Data collected of teacherstudent interactions over a period of time could determine whether regressive relationships exist, meaning that the teacher is at lower level of racial identity development than student(s), making it highly improbable student needs would be met. Further, such analyses would provide specific and relevant information for developing staff development on meeting the needs of all students. Observation and analysis of interactions could be extended to other school personnel and students in order to provide material for ongoing staff development. Trainings could occur on a yearly basis, so all staff members are well informed on cultural competencies (Vera, Buhin, and Isacco 2009).

\section{Higher Education}

Training for professors working with students from different cultural backgrounds at the university level is also an important component for cultural competencies. Specifically, training focusing on self-awareness of one's own biases is the beginning stage for recognizing microaggressions. The university where the microaggression experiences were presented in this article provides staff and faculty with diversity training in the form of knowledge of various aspects of diversity. However, there is no university or institutional level training for personnel regarding self-awareness of personal bias and how these can be expressed outside an individuals' awareness as in the case of microaggressions. No matter how self-aware professors might become with training to fight microaggression there is always the chance one could commit another microaggression. Further training would be needed on how to effectively engage with a student who might bring a microaggression concern to a professor. In such cases it is important to validate the "lived experienced" of the person communicating a microaggression. Sue and Sue (2013) consider the decision victims of microaggressions are faced with as one of the more perplexing ones related to minority status stress.

Catch twenty-two is the term used to denote the added stress one might experience when deciding whether to confront someone about their lived experience of a microaggression. Specifically, when the person to be confronted holds power over the other as in the case of the professor and the two doctoral students in this article, the potential for stress is even more probable than when the accused does not hold power over the victim(s). Accordingly, victims' thinking process goes something like: "if I confront the professor, she might get upset and think I'm accusing her of being a racist or something, and worst yet she might punish me by lowering my course grade or even giving me a failing grade." If the victim does not confront the professor (in this case) and she does not have another trusting supporting person to share the experi- 
ence with and receive validation of her lived experience, she will likely internalize the experience and might doubt her own reality of what she experienced.

This potential for turning the microaggression inward is illustrated when upon receiving the email for her professor student M states, "Is she correct and should I believe that I am not capable of making it in her class next semester?" "Maybe I should follow her advice and take another class next semester instead of hers." Similarly, Student K recalled racial bias from the professor prior to the microaggression reported here when she asserted, "I thought I had dispelled the irrational belief that I was not smart enough to understand doctoral level math. However, a pesky inkling of self-doubt was trying to resurface. Refusing to allow self-doubt to reenter my consciousness, I spent long hours studying alone, and with peers, to make sure I met the learning objectives and earned a decent grade. I did not attempt to address the reasons my professor doubted me." Internalizing microaggressions results in symptoms such as depression, anxiety, high blood pressure, hopelessness, lower achievement and success (Franklin and Boyd-Franklin 2000).

\section{CONCLUSION}

The concept microaggressions has gained recognition in the psychology and counseling fields for its utility in understanding and addressing racism and other forms of discrimination/oppression experienced by individuals from marginalized groups. In article, microaggressions were used as the primary concept for understanding two female doctoral students experience with a university professor. Additionally, the concepts minority stress and Triple-Quandary provided context to the students' experience of microaggressions. Evaluating the microaggression of the students in this manuscript demonstrated three noteworthy findings: (1) both received similar teachings from parents that were consistent with Triple Quandary, (2) both developed different styles of coping with racism, and (3) the importance of consistency in response by trusted adults throughout a person's educational journey. The outcome for the students in this manuscript was positive due to the initial teachings by their parents and the advocacy on their behalf by their Black advisor. However, far too many students of color in United States schools from kindergarten through university terminal degree levels are "derailed" from achieving their American dream because of educators who oftentimes have very good intentions yet lack knowledge and training to effectively respond to microaggressions. With proper training teachers at all levels of education can become adept at eliminating the negative consequences of microaggressions from the lives of far too many students. 


\section{REFERENCES}

Allen, Walter R. 1992. "The Color of Success: African-American College Student Outcomes at Predominantly White and Historically Black Public Colleges and Universities." Harvard Educational Review 62 (1): 26-45.

Banks, Kira Hudson. 2010. "African American College Students' Experience of Racial Discrimination and the Role of College Hassles." Journal of College Student Development 51 (1): 23-34.

Barr, Simone C., and Helen A. Neville. 2008. "Examination of the Link Between Parental Racial Socialization Messages and Racial Ideology Among Black College Students." Journal of Black Psychology 34 (2): 131-155.

Boykin, A. Wade, and Forrest D. Toms. 1985. "Black Child Socialization: A Conceptual Framework." "In Black Children: Social, Educational, and Parental Environments, edited by Harriette Pipes McAdoo and John Lewis McAdoo, 33-51. Beverly Hills, CA: Sage.

Carter, Dorinda J. 2008. "Achievement as Resistance: The Development of a Critical Race Achievement Ideology among Black Achievers." Harvard Educational Review 78 (3): 466-497.

Carter Andrews, Dorinda J. 2012. "Black Achievers' Experiences With Racial Spotlighting and Ignoring in a Predominantly White High School." Teachers College Record 114, 1-46.

Colbert, Robert, D. in press. "From Jim Crow South to Academia: One Brother's Counternarrative for School Counselor Social Advocacy." National Journal of Urban Education and Practice.

Colbert, Robert, D. 1991. "Untapped Resource: African American Parental Perceptions." Elementary School Guidance \& Counseling 26 (2): 96-105.

Fleming, Jacqueline. 1984. Blacks in College. San Francisco: JosseyBass.

Franklin, Anderson J., and Nancy Boyd-Franklin. 2000. "Invisibility Syndrome: A Clinical Model of the Effects of Racism on AfricanAmerican Males." American Journal of Orthopsychiatry 70: 33-41.

Franklin, Anderson J. 1999. "Invisibility Syndrome and Racial Identity Development in Psychotherapy and Counseling African American Men." The Counseling Psychologist 27: 761-793.

Greer, Tawanda M. 2008. "Racial and Ethnic-related Stressors as Predictors of Perceived Stress and Academic Performance for Afri- 
can American students at a Historically Black College and University." The Journal of Negro Education 77: 60-71.

Greer, Tawanda M., and Porschia Brown. 2011. "Minority Status Stress and Coping Processes Among African American College Students." Journal of Diversity in Higher Education 4: 26-38.

Greer, Tawanda M., and Kathleen Chwalisz. 2007. "Minority-related Stressors and Coping Processes Among African American College Students." Journal of College Student Development 48 (4): 388-404.

Gregory, Anne, Russell J. Skiba, and Pedro A. Noguera. 2010. "The Achievement Gap and the Discipline Gap Two Sides of the Same Coin?.” Educational Researcher 39 (1): 59-68.

Helms, Janet, E. 2003. "Racial Identity on the Social Environment." In Multicultural Counseling in Schools; A Practical Handbook, edited by Paul B. Pedersen and John C. Carey, 44-58. Boston, MA: Allyn and Bacon.

Johnson-Bailey, Juanita, Thomas S. Valentine, Ronald M. Cervero, and Tuere A. Bowles. 2008. "Lean On Me: The Support Experiences of Black Graduate Students." The Journal of Negro Education 77 (4): 365-381.

Marshall, Sheree. 1995. "Ethnic Socialization of African American Children: Implications for Parenting, Identity Development, and Academic Achievement." Journal of Youth and Adolescence 24 (4): 377-396.

McAdoo, Harriette Pipes. 2002. Black Children: Social, Educational, and Parental Environments. Sage.

Roth, Susan, and Lawrence J. Cohen. 1986. "Approach, Avoidance, and Coping with Stress." American Psychologist 41 (7): 813-819.

Silver, Roxane L., and Camille B. Wortman. 1980. "Coping with Undesirable Life Events." In Human Helplessness: Theory and Applications edited by J. Garber \& M. EP Seligman, 279-340. New York: Academic Press.

Smedley, Brian D., Hector F. Myers, and Shelly P. Harrell. 1993. "Minority-Status Stresses and the College Adjustment of Ethnic Minority Freshmen." Journal of Higher Education 64 (4): 434-452.

Sue, Derald Wing, and David Sue. 2013. Counseling the Culturally Diverse: Theory and Practice. New York, NY: John Wiley.

Sue, Derald Wing, Christina M. Capodilupo, Gina C. Torino, Jennifer M. Bucceri, Aisha Holder, Kevin L. Nadal, and Marta Esquilin. 2007. "Racial Microaggressions in Everyday Life: Implications for Clinical Practice.” American Psychologist 62 (4): 271-286. 
U.S. Department of Education, National Center for Education Statistics 2015. Digest of Education Statistics, 2013 (NCES 2015-011), (nces.ed.gov).

Vera, Elizabeth M., Larisa Buhin, and Anthony Isacco. 2009. "The Role of Prevention in Psychology's Social Justice Agenda." In Realizing Social Justice: The Challenge of Preventive Interventions, edited by Maureen E. Kenny, Arthur M. Horne, Pamela. Orpinas, and Le'Roy E. Reese, 79-96. American Psychological Association. 